\title{
Culturable bacteria isolated from seven high-altitude ice cores on the Tibetan Plateau
}

\author{
YONGQIN LIU, ${ }^{1,2,3}$ JOHN C. PRISCU, ${ }^{4}$ TANDONG YAO, ${ }^{1,2,3}$ \\ TRISTA J. VICK-MAJORS, ${ }^{5}$ ALEXANDER B. MICHAUD, ${ }^{6}$ LIANG SHENG ${ }^{1}$ \\ ${ }^{1}$ Key Laboratory of Tibetan Environment Changes and Land Surface Processes, Institute of Tibetan Plateau Research, \\ Chinese Academy of Sciences, Beijing 100101, China \\ ${ }^{2}$ CAS Center for Excellence in Tibetan Plateau Earth Sciences, Chinese Academy of Sciences, Beijing 100101, China \\ ${ }^{3}$ University of Chinese Academy of Sciences, Beijing 100049, China \\ ${ }^{4}$ Department of Land Resources and Environmental Sciences, Montana State University, Bozeman, Montana 59717, USA \\ ${ }^{5}$ University of Montana, Flathead Lake Biological Station, 32125 Bio Station Lane, Polson, Montana 59860, USA \\ ${ }^{6}$ Department of Bioscience, Center for Geomicrobiology, Aarhus University, 8000 Aarhus C, Denmark \\ Correspondence: Yongqin Liu <yqliu@itpcas.ac.cn>
}

\begin{abstract}
Microorganisms are the most abundant organisms on Earth, and microbial abundance records preserved in ice cores have been connected to records of environmental change. As an alternative to high resolution abundance records, which can be difficult to recover, we used culture-dependent and culture-independent methods to examine bacteria in glacier ice from the Tibetan Plateau (TP). We recovered a total of 887 bacterial isolates from ice cores of up to $164 \mathrm{~m}$ in depth retrieved from seven glaciers, located across the TP. These isolates were related to 53 genera in the Actinobacteria, Firmicutes, Bacteroidetes, and Proteobacteria, with 13 major genera accounting for $78 \%$ of isolates. Most of the genera were common across the geographic region covered by our sampling, but there were differences in the genera recovered from different depths in the ice, with the deepest portions of the ice cores dominated by a single genus (Sporosarcina). Because microorganisms deposited on glaciers must survive atmospheric transport under a range of temperatures, temperature tolerance should be an important survival mechanism. We tested isolate growth across a range of temperatures $\left(0-35^{\circ} \mathrm{C}\right)$, and found psychrotolerance to be common. Together, our results show that ice depth, and by extension age, are characterized by different types of microorganisms, providing new information about microbial records in ice.
\end{abstract}

KEYWORDS: ice core, microbiology, mountain glaciers

\section{INTRODUCTION}

Glacier ice is a globally significant reservoir of microorganisms $\left(9.6 \times 10^{25}\right.$ cells) that are chronologically deposited for hundreds or thousands of years (Priscu and others, 2007). Ice cores drilled from the accumulation zone of glaciers provide a bacterial record in an extreme environment subject to low temperature, low nutrient, high-UV radiation in the surface snow, and darkness below the surface (Christner and others, 2000). Bacterial diversity in ice cores has been studied using culture-dependent (Miteva and others, 2009; An and others, 2010; Segawa and others, 2010) and culture-independent techniques (Christner and others, 2000; Miteva and others, 2004; Zhang and others, 2008b). Descriptions of community compositions, based on bacterial 16S rRNA gene clone libraries, from different ice core locations and layers reflect the surrounding ecosystem, precipitation events, and atmospheric dust (Miteva and others, 2009; An and others, 2010). While culturable bacteria only represent $1 \%$ of the total bacterial community, viable bacteria recovered from ice cores also show geographic and seasonal distributions related to climate and the surrounding environment (Christner and others, 2000; Zhang and others, 2007). Both culturable and unculturable bacterial abundance and diversity metrics have utility as possible climate proxies in ice cores (Yao and others, 2008; Miteva and others, 2009; Santibanez and others, 2016).
Culture-dependent methods are useful techniques for exploring the relationship between bacteria deposited on ice and climatic and environmental change. Betweendepth differences in culturable bacteria recovered from glacier ice in the Himalaya, Greenland, and the Muztag Ata Glacier in China were related to past local climate conditions and global atmospheric circulations (Xiang and others, 2005a; Zhang and others, 2007; Miteva and others, 2009), demonstrating the linkages between ice-encased bacteria and the environment at the time of deposition. In addition to the environmental importance, the recovery of viable bacteria from ice cores demonstrates that a subset of the total bacterial assemblage preserved in the ice remains viable, and has the potential to reveal previously unknown adaptations for survival in icy environments. However, culturable bacteria from glacial ice have been recovered from fewer than ten ice cores to date around world (Christner and others, 2000; Christner and others, 2003; Miteva and others, 2004; Xiang and others, 2005a; Zhang and others, 2007; Miteva and others, 2009; Zhang and others, 2010; Margesin and Miteva, 2011; Shen and others, 2018). Especially in the Tibetan Plateau (TP) which contains the largest low-latitude glacier-covered area in the world (Qiu, 2008), bacteria have only been isolated from five ice cores (Xiang and others, 2005a; Zhang and others, 2007; An and others, 2010; Zhang and others, 2010; Shen and others, 
2018). Detected ice core bacteria were dominated by Actinobacteria, Proteobacteria, Bacteroidetes, and Firmicutes (Shen and others, 2018), but the limited number of studies restrict our understanding of the taxonomic biodiversity in glacial ices on the TP. Moreover, the separate studies of culturable bacteria along depth in individual ice cores cannot be used to reveal patterns in bacterial biogeography across the plateau.

Different isolation methods also hinder understanding of the general features of bacteria in ice cores by impeding efforts to compare data across studies. In particular, incubation temperature is an important factor in determining the abundance and diversity of bacteria that can be cultivated. Christner and others (2003) incubated paired ice core samples at 4 and $22{ }^{\circ} \mathrm{C}$, and found that incubation at the higher temperature led to the recovery of fewer distinct bacterial types (isolates) than incubation at low temperature, however, once recovered from low temperature incubations, isolates would grow at $22{ }^{\circ} \mathrm{C}$ (Christner and others, 2003). Various incubation temperatures were used in different studies of ice cores in the TP (Xiang and others, 2005a; Zhang and others, 2007; Zhang and others, 2010), which could lead to differences in the recovered bacteria that were unrelated to the ice cores themselves.

To broadly explore the diversity and distribution patterns of viable bacteria in ice cores, we studied 887 bacterial isolates from seven ice cores and constructed three 16S rRNA clone libraries from three of these ice cores, representing the most intensive study of its kind in the western TP. The seven ice cores were drilled from different geographic and climatic areas of the TP (Fig. 1). Our isolate collection expands the known diversity of culturable bacteria in high-altitude ice cores, and documents their viability at different culturing temperatures. Additionally, by using the culture dependent and independent methods in conjunction, we compare the culturable bacterial diversity of whole ice cores with the community composition revealed by $16 \mathrm{~S}$ rRNA gene clone libraries.

\section{MATERIALS AND METHODS}

\section{Ice core sites}

Ice cores were collected from seven different glaciers: Ulugh Muztagh (MZTG), Muji (MJ), Muztag Ata (MUA), Yuzhufeng

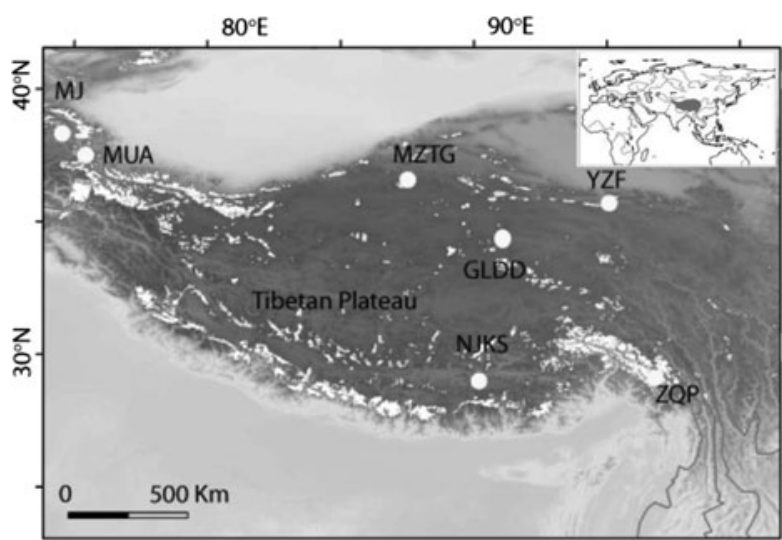

Fig. 1. Seven ice core sampling sites on the TP, Ulugh Muztagh (MZTG), Muji (MJ), Muztag Ata (MUA), Yuzhufeng (YZF), Geladandong (GLDD), Noijin Kangsang (NJKS), and Zuoqiupu (ZQP). Horizontal and vertical tick marks are latitude and longitude marks, respectively. The gray area in the small inset map shows the location of the TP.
(YZF), Geladandong (GLDD), Noijin Kangsang (NJKS), and Zuoqiupu (ZQP) (Fig. 1), all of which were higher than $5300 \mathrm{~m}$ above mean sea level (a.s.l.) (Table 1). MZTG, MJ, and MUA glaciers were located in the alpine desert zone of the western portion of the TP. YZF and GLDD glaciers are surrounded by alpine steppe and desert in the northern part of the TP. NJKS is surrounded by steppe in the southern portion of the plateau while ZQP is near forested area in the southeastern portion of the TP.

\section{Sampling}

Ice cores were drilled from the accumulation zones of the glaciers to depths of 28-164 m (Table 1), and transported frozen to the laboratory. The drill was designed and constructed by the Cold and Arid Regions Environmental and Engineering Research Institute, CAS. Ice cores with diameters of $7 \mathrm{~cm}$ were split lengthwise into four portions for different analyses. One portion was utilized for microbial analysis and cut into $5 \mathrm{~cm}$ sections along depth using a bandsaw in a walk-in-freezer $\left(-20^{\circ} \mathrm{C}\right)$. All ice cores were sampled from the top to the bottom. Each sample was decontaminated by cutting away the $1 \mathrm{~cm}$ outer annulus with a sterilized sawtooth knife, before rinsing the remaining inner cores with cold ethanol $(95 \%)$, and finally with cold, triple-autoclaved water (Christner and others, 2005). The decontaminated ice samples were placed in autoclaved containers and melted at $4{ }^{\circ} \mathrm{C}$.

\section{Enrichment and isolation}

In total 489 samples of meltwater from ice cores were used for enrichment and isolation (Table 1). Cultures were named using ice core abbreviation and incubation temperature, followed by an ice core section number, which corresponded with depth of sampling (Table 1). All sections of MZTG4, MJ4, MUA4, GLDD4, YZF4, NJKS4, and all sections of ZQP4 were incubated aerobically at $4{ }^{\circ} \mathrm{C}$. YZF24, NJKS24, and ZQP24 were incubated aerobically at $24^{\circ} \mathrm{C}$. Each isolate and its respective depth of origin are listed in Supplemental Table S1. Cultures were obtained by spreading a $200 \mu \mathrm{L}$ sample of meltwater directly onto the surface of agar-solidified R2A media (Reasoner and Geldreich, 1985). The first colonies were visible after $7 \mathrm{~d}$ of incubation at $24^{\circ} \mathrm{C}$ and $15 \mathrm{~d}$ at $4{ }^{\circ} \mathrm{C}$. All samples were incubated for 2 months at $24{ }^{\circ} \mathrm{C}$ and 4 months at $4{ }^{\circ} \mathrm{C}$, and checked every 2 weeks for growth. The maximum number of colonies of visibly different morphology (between one and six) were picked from each plate and purified by sub-culturing five to six times on new R2A agar media. The purified isolates were then stored at $-80{ }^{\circ} \mathrm{C}$ in $30 \%$ glycerol solution. As a control, $200 \mu \mathrm{L}$ deionized sterile water was spread on five R2A plates and incubated at each temperature. No colonies grew on the control plates.

\section{DNA extraction, polymerase chain reaction (PCR) amplification, and sequencing of 165 rRNA gene of isolates}

Genomic DNA of the 887 isolates obtained was extracted using the phenol/chloroform method (Shen and others, 2012). DNA extracted from isolates was used as template to amplify the bacterial $16 \mathrm{~S}$ rRNA genes. PCR was carried out in a final volume of $50 \mu \mathrm{L}$ using $2 \mu \mathrm{L}$ template DNA, 3 
Table 1. Description of the ice cores collected and the total number of isolates recovered from each core. The number of samples for each ice core refers to the number of sections cut from each ice core at $5 \mathrm{~cm}$ intervals, thus the number of samples varies as a function of ice core length (core depth)

\begin{tabular}{|c|c|c|c|c|c|c|}
\hline Ice core & Altitude (m a.s.l.) & Core depth $(\mathrm{m})$ & Culture ID & Culture temperature $\left({ }^{\circ} \mathrm{C}\right)$ & No. of samples & No. of isolates \\
\hline Ulugh Muztagh & 5770 & 164 & MZTG4 & 4 & 160 & 217 \\
\hline Muji & 5300 & 28 & MJ4 & 4 & 10 & 18 \\
\hline Muztag Ata & 6300 & 90 & MUA4 & 4 & 20 & 30 \\
\hline Geladandong & 5720 & 47 & GLDD4 & 4 & 15 & 32 \\
\hline \multirow[t]{2}{*}{ Yuzhufeng } & 5670 & 161 & YZF4 & 4 & 63 & 166 \\
\hline & & & YZF24 & 24 & 90 & 137 \\
\hline \multirow[t]{2}{*}{ Noijin Kangsang } & 5960 & 33 & NJKS4 & 4 & 15 & 64 \\
\hline & & & NJKS24 & 24 & 27 & 36 \\
\hline \multirow[t]{2}{*}{ Zuoqiupu } & 5600 & 97 & ZQP4 & 4 & 22 & 74 \\
\hline & & & ZQP24 & 24 & 84 & 113 \\
\hline
\end{tabular}

$\mu \mathrm{L} \mathrm{MgCl}_{2}, 4 \mu \mathrm{L}$ each $\mathrm{dNTP}, 0.5 \mu \mathrm{L}$ each primer, and $0.2 \mu \mathrm{L}$ Taq DNA polymerase, and $35 \mu \mathrm{L} \mathrm{ddH}_{2} \mathrm{O}$ using the primers $27 \mathrm{~F}$ (5'-AGAGTTTGATCTGGCTCAG-3') and 1492R (5'GGTTA CCTTGTTACGACTT-3') (Lane, 1991). The PCR cycle included an initial incubation at $94{ }^{\circ} \mathrm{C}$ for $5 \mathrm{~min}, 28$ cycles of $94{ }^{\circ} \mathrm{C}$ for $0.5 \mathrm{~min}, 56{ }^{\circ} \mathrm{C}$ for $1 \mathrm{~min}$, and $72{ }^{\circ} \mathrm{C}$ for $1 \mathrm{~min}$, followed by a final extension at $72{ }^{\circ} \mathrm{C}$ for $8 \mathrm{~min}$. The PCR products were purified using an agarose gel DNA purification kit (TaKaRa Co., Dalian, China), and then partially sequenced directly off of the primers (1492R, 43 isolates in YZF; 27F, 844 isolates) with BigDye terminator v3.1 chemistry on an ABI PRISM 377-96 sequencer.

\section{DNA EXTRACTION, PCR AMPLIFICATION, AND 165 RRNA GENE CLONE LIBRARY CONSTRUCTION FROM BULK MELTWATER}

Approximately $2 \mathrm{~L}$ of meltwater was collected from each of the entire length of the ice core YZF, NJKS, and ZQP ice cores, and filtered through a $0.22 \mu \mathrm{m}$ filter (Millipore). DNA was extracted from the filters using phenol-chloroform method (Kan and others, 2006). To assess if contamination was introduced during DNA extraction, a negative parallel control was established by filtering $2 \mathrm{~L}$ of autoclaved deionized water using the same method as described above. DNA preparations from both the sample and negative control were used as templates to amplify the bacterial $16 \mathrm{~S}$ rRNA genes with the universal primer pair 27F and 1492R (Lane, 1991). The PCR program was as follows: after an initial incubation at $94{ }^{\circ} \mathrm{C}$ for $5 \mathrm{~min}, 30$ cycles were run at $94{ }^{\circ} \mathrm{C}$ for $1 \mathrm{~min}, 56{ }^{\circ} \mathrm{C}$ for $1 \mathrm{~min}$, and $72{ }^{\circ} \mathrm{C}$ for $1.5 \mathrm{~min}$, followed by a final extension at $72{ }^{\circ} \mathrm{C}$ for $8 \mathrm{~min}$.

The PCR products were purified using an agarose gel DNA purification kit (TaKaRa Co., Dalian, China), ligated into pGEM-T vector (TaKaRa Co., Dalian, China), and then transformed into Escherichia coli $\mathrm{DH} 5 \alpha$. The presence of inserts was checked by colony PCR. In total 150, 110, and 110 clones in YZF, NJKS, and ZQP were selected for sequencing, respectively.

\section{Growth at different temperatures}

The growth of 32 isolates of different morphological groups from YZF4 was tested in R2A liquid media at 0, 5, 10, 15, 20, 30, and $35^{\circ} \mathrm{C}$. The 32 isolates consisted of: eight Pseudomonas; seven Flavobacterium; three Lysobacter and Psychrobacter, two Cryobacterium, Microbacterium, and
Stenotrophomona; and one each from Dyadobacter, Leifsonia, Rhodococcus, Sphingobacterium, and Massilia. Cultures were measured using the optical density at 600 $\mathrm{nm}\left(\mathrm{OD}_{600}\right)$ after obvious growth was observed in most samples. All isolates were grown and measured in triplicate.

\section{Phylogenetic analysis}

$16 \mathrm{~S}$ rRNA gene sequences were aligned at the genus level against the SILVA reference database (Pruesse and others, 2007). All sequences obtained from the clone library were examined for chimeric artifacts using the Pintail tool (http:// www.bioinformatics-toolkit.org). Clones identified as potential chimeras were discarded. To determine the isolates' closest officially named phylogenetic neighbors initial identification was carried out using BLASTn (Altschul and others, 1997) against the database containing type strains with validly published prokaryotic names (the EzTaxon-e server; http://eztaxon-e.ezbiocloud.net/) (Kim and others, 2012). The closest sequences and the associated environment from which the sequence was recovered were retrieved from the NCBI (http://www.ncbi.cih.gov) using BLASTn.

\section{Statistical analysis}

Coverage of clone libraries was calculated using the equation: Coverage $=[1-(N /$ Individuals $)] \times 100 \%$, where $N$ is the number of clones that occurred only once (Kemp and Aller, 2004). Comparisons of isolate assemblages from 4 and $24{ }^{\circ} \mathrm{C}$ were conducted by pooling together the data from all depths of each ice core. Analyses of similarity (ANOSIM) were performed using PAST (Hammer and others, 2001) to determine the differences among bacterial assemblages derived from 4 and $24{ }^{\circ} \mathrm{C}$ incubations and clone libraries. Distribution patterns of isolates and clone sequences were analyzed using non-metric multidimensional scaling (nMDS) based on Bray-Curtis dissimilarity. Analyses were carried out with R v2.14 (Wood, 2006) with the packages vegan (Oksanen and others, 2009) and gplot (Warnes and others, 2009).

\section{Nucleotide sequence accession numbers}

The nucleotide sequences of partial 16S rRNA genes have been deposited in the GenBank database under accession numbers KF294941-KF295827 for isolates and KX119594KX119940 for clones. All 887 isolates were stored at $-80^{\circ} \mathrm{C}$ 
in $30 \%$ glycerol solution at the Institute of Tibetan Plateau Research, CAS, and are available for any study on request.

\section{RESULTS}

We isolated 887 bacterial strains from different depths in seven ice cores from the TP (total sample $n=506$; Supplemental Table S1). The isolates were affiliated with six groups. Actinobacteria and Firmicutes were the most abundant, accounting for $21 \%$ of total isolates, followed by Bacteroidetes (16\%), $\gamma$-Proteobacteria (16\%), $\beta$-Proteobacteria (14\%), and $\alpha$-Proteobacteria (13\%).

All isolates were classified into 53 genera. Genera containing isolates that contributed $\geqslant 10 \%$ of the total number of isolates were labeled as 'abundant', while those that were less abundant $(<5 \%)$, but found in greater than or equal to four ice cores, were labeled as 'common'. Isolates affiliated with the genera Bacillus (Firmicutes), Flavobacterium (Bacteroidetes), and Pseudomonas ( $\gamma$-Proteobacteria) were the most abundant across all samples, accounting for 14,12 , and $10 \%$ of total isolates (the abundant group). Isolates in the genera Arthrobacter, Microbacterium, and Rhodococcus (Actinobacteria); Brevundimonas and Sphingomonas ( $\alpha$-Proteobacteria); and Polaromonas and Massilia ( $\beta$-Proteobacteria) were less abundant, accounting for $<5 \%$ of total isolates, but were commonly found across samples from four to seven ice cores (common group). Isolates in genera Cryobacterium, Paenisporosarcina, and Burkholderia accounted for $5-7 \%$ of total isolates, but dominated in only one or two ice cores (NJKS and YZF, GLDD and MZTG, or ZQP, respectively; Table 2), and were therefore neither common, nor abundant. In sum, these 13 genera contained $78 \%$ of all isolates. The other 40 genera existed in one or two ice cores, accounted for $<5 \%$ of all isolates and were considered 'rare' (Supplemental Table S1).

There were no marked geographic differences in the taxon composition from the northern (MZTG, MJ, and MU) and southern (GLDD, YZF, NJKS, and ZQP) regions of the TP ( $t$ test, $P>0.01$ ). Isolates from different depths, however, showed differences in diversity and represented genera. To avoid characterizing samples based on rare isolates, we focused on genera represented by more than five isolates. The shallower depths of the ice cores $(0-40 \mathrm{~m})$ yielded the greatest diversity of isolates, covering 18 different genera, while isolates from the mid-depths $(40-80 \mathrm{~m})$ represented five genera, with only a single genus (Sporosarcina) recovered below $80 \mathrm{~m}$ (Table 3). Isolates from the genus Bacillus were present at all depths $<100 \mathrm{~m}$, and were the sole genus represented from 80 to $100 \mathrm{~m}$, while isolates of the genus Sporosarcina were the only genus recovered from depths $>100 \mathrm{~m}$ (Table 3). Besides genus Bacillus, isolates in the genera Flavobacterium, Pseudomonas, and Brevundimonas were obtained from ice 40-80 m (Table 3).

Isolates from our ice cores were identified based on $16 \mathrm{~S}$ rRNA gene sequence similarity to published type strains in the EZTAXON database. Similarity ranged from 90 to $100 \%$, with $12 \%$ of total isolates $<97 \%$ similar to the published type strains. These $<97 \%$ similar isolates are potential novel species (Stackebrandt and Goebel, 1994). When queried against the $\mathrm{NCBI}$ database, our isolates matched cultured or uncultured bacterial clones from a wide variety of environments with $95-100 \%$ similarity. Forty-two percent of these nearest relatives were recovered from the cryosphere, i.e. snow, glacier, permafrost, Arctic, and Antarctica, while 27, 14, and 7\% were also found in soil,

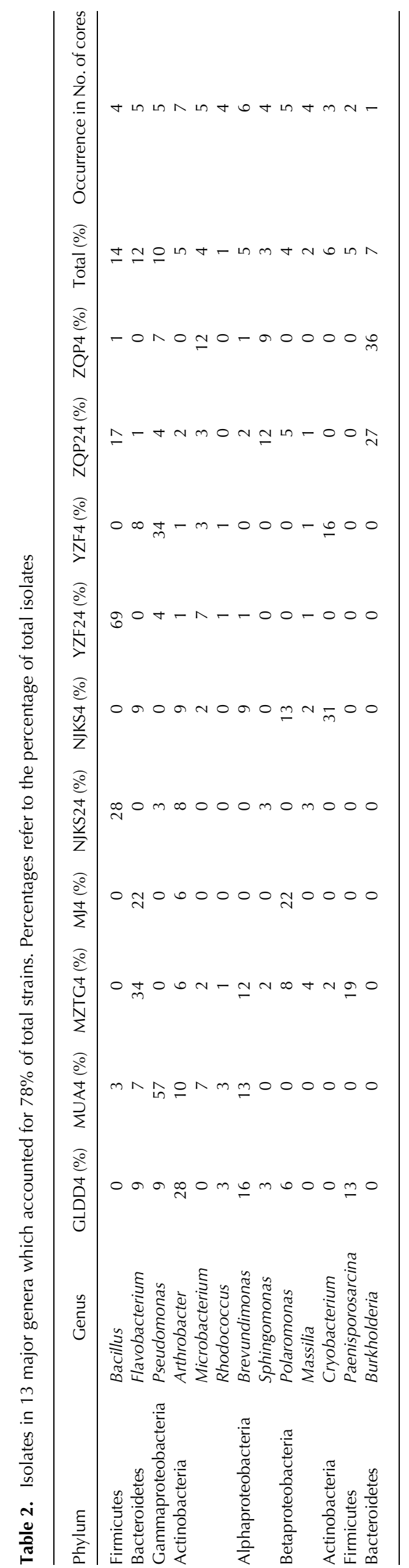


Table 3. Distribution of isolated genera along depth. No. represents number of isolates in each genus. Only genera containing more than five isolates are shown

\begin{tabular}{|c|c|c|c|c|c|c|c|c|c|c|c|c|c|c|c|c|}
\hline & \multicolumn{2}{|l|}{$0-20 \mathrm{~m}$} & \multicolumn{2}{|l|}{$21-40 \mathrm{~m}$} & \multicolumn{2}{|l|}{$41-60 \mathrm{~m}$} & \multicolumn{2}{|l|}{$61-80 \mathrm{~m}$} & \multicolumn{2}{|c|}{$81-100 \mathrm{~m}$} & \multicolumn{2}{|c|}{$101-120 \mathrm{~m}$} & \multicolumn{2}{|c|}{$121-140 \mathrm{~m}$} & \multicolumn{2}{|c|}{$141-160 \mathrm{~m}$} \\
\hline & Genus & No. & Genus & No. & Genus & No. & Genus & No. & Genus & No. & Genus & No. & Genus & No. & Genus & No. \\
\hline \multirow[t]{15}{*}{ Cultures in $4{ }^{\circ} \mathrm{C}$} & Burkholderia & 34 & Pseudomonas & 51 & Bacillus & 35 & Flavobacterium & 21 & Bacillus & 14 & Sporosarcina & 9 & Sporosarcina & 11 & Sporosarcina & 13 \\
\hline & Flavobacterium & 29 & Flavobacterium & 36 & Pseudomonas & 20 & Bacillus & 12 & & & & & & & & \\
\hline & Bacillus & 25 & Burkholderia & 24 & Flavobacterium & 14 & Sphingomonas & 8 & & & & & & & & \\
\hline & Arthrobacter & 23 & Bacillus & 20 & Brevundimonas & 6 & & & & & & & & & & \\
\hline & Cryobacterium & 23 & Polaromonas & 15 & & & & & & & & & & & & \\
\hline & Polaromonas & 22 & Brevundimonas & 15 & & & & & & & & & & & & \\
\hline & Brevundimonas & 12 & Psychrobacter & 15 & & & & & & & & & & & & \\
\hline & Pseudomonas & 12 & Microbacterium & 13 & & & & & & & & & & & & \\
\hline & Sphingomonas & 11 & Sphingobacterium & 10 & & & & & & & & & & & & \\
\hline & Pedobacter & 9 & Cryobacterium & 9 & & & & & & & & & & & & \\
\hline & Brevibacterium & 8 & Sphingomonas & 7 & & & & & & & & & & & & \\
\hline & Caulobacter & 8 & Stenotrophomonas & 7 & & & & & & & & & & & & \\
\hline & Microbacterium & 7 & Arthrobacter & 6 & & & & & & & & & & & & \\
\hline & Brevibacillus & 6 & Pedobacter & 6 & & & & & & & & & & & & \\
\hline & Massilia & 6 & & & & & & & & & & & & & & \\
\hline \multirow[t]{6}{*}{ Cultures in $24^{\circ} \mathrm{C}$} & Bacillus & 24 & Bacillus & 19 & Bacillus & 35 & Bacillus & 12 & Bacillus & 14 & & & & & & \\
\hline & Burkholderia & 21 & Burkholderia & 10 & & & & & & & & & & & & \\
\hline & Brevibacterium & 8 & Polaromonas & 6 & & & & & & & & & & & & \\
\hline & Sphingomonas & 8 & & & & & & & & & & & & & & \\
\hline & Brevibacillus & 6 & & & & & & & & & & & & & & \\
\hline & Pseudomonas & 6 & & & & & & & & & & & & & & \\
\hline
\end{tabular}


Table 4. The source environments for the closest relatives of the 13 major genera recovered from ice cores sampled in this study. Closest relatives were determined as those with $99 \%$ similarity in the NCBI database using BLASTn

\begin{tabular}{|c|c|c|c|c|c|c|c|}
\hline \multirow[t]{2}{*}{ Phylum } & \multirow[t]{2}{*}{ Genus } & \multirow[t]{2}{*}{ Total of isolates } & \multicolumn{5}{|c|}{ No. of the nearest clones from various environments } \\
\hline & & & Cold environment & Soil & Aquatic environment & Plant & Others \\
\hline \multirow[t]{4}{*}{ Actinobacteria } & Arthrobacter & 42 & 17 & 9 & 10 & 1 & 5 \\
\hline & Microbacterium & 34 & 6 & 14 & 2 & 11 & 1 \\
\hline & Rhodococcus & 7 & 2 & 2 & 2 & 0 & 1 \\
\hline & Cryobacterium & 49 & 49 & 0 & 0 & 0 & 0 \\
\hline Firmicutes & Paenisporosarcina & 45 & 42 & 1 & & 0 & 2 \\
\hline \multirow[t]{2}{*}{ Bacteroidetes } & Flavobacterium & 103 & 88 & 4 & 8 & 0 & 3 \\
\hline & Burkholderia & 57 & 16 & 14 & 0 & 17 & 10 \\
\hline \multirow[t]{2}{*}{ Alphaproteobacteria } & Brevundimonas & 45 & 20 & 7 & 2 & 10 & 6 \\
\hline & Sphingomonas & 29 & 5 & 8 & 10 & 0 & 6 \\
\hline \multirow[t]{2}{*}{ Betaproteobacteria } & Polaromonas & 37 & 26 & 9 & 2 & 0 & 0 \\
\hline & Massilia & 18 & 5 & 7 & 1 & 1 & 4 \\
\hline
\end{tabular}

aquatic (marine, lake, river, and cold spring), and plant-associated environments, respectively. The other $10 \%$ were previously found in air, animal, and other environments (i.e. aviation kerosene, activated sludge, drinking water, and volcanic ash; Supplemental Table S1). The genera Cryobacterium, Polaromonas, Flavobacterium, and Paenisporosarcina were dominated $(100,93,85$, and $70 \%$ of all strains in each genus, respectively) by isolates related to organisms or clones from the cryosphere. Strains in the genera Arthrobacter, Microbacterium, Bacillus, Burkholderia, Brevundimonas, Sphingomonas, Massilia, and Pseudomonas were mostly (60$99 \%$ ) related to soil, plant, aquatic, and other environments (Table 4, Supplemental Table S1).

Temperature incubation experiments showed that ice core isolates possess the ability to grow at wide temperature ranges. Twenty-six strains grew from 0 to $35^{\circ} \mathrm{C}$, while the other six strains grew from 0 to $30^{\circ} \mathrm{C}$. Psychrophilic bacteria are defined as those with optimal growth temperature at or below $15{ }^{\circ} \mathrm{C}$ and no growth occurring at $20^{\circ} \mathrm{C}$, while psychrotolerant bacterial have an optimal growth temperature higher than $20{ }^{\circ} \mathrm{C}$ with growth occurring down to $4{ }^{\circ} \mathrm{C}$ (Bowman and others, 1997). All strains could be identified as possessing psychrotolerant growth characteristics, but none of the strains displayed psychrophilic growth (Bowman and others, 1997) characteristics (Fig. 2). Thirty-one percent of all isolates (ten strains) had optimum growth temperatures $\leqslant 15^{\circ} \mathrm{C}$ (Fig. 2a). Thirteen strains had an optimum growth temperature between 15 and $20{ }^{\circ} \mathrm{C}$ (Fig. 2b). The other nine isolates grew at low temperatures, so could not be classified as mesophiles, but had optimum growth temperatures of 30 (Fig. 2c) to $35^{\circ} \mathrm{C}$ (Fig. $2 \mathrm{~d}$ ).

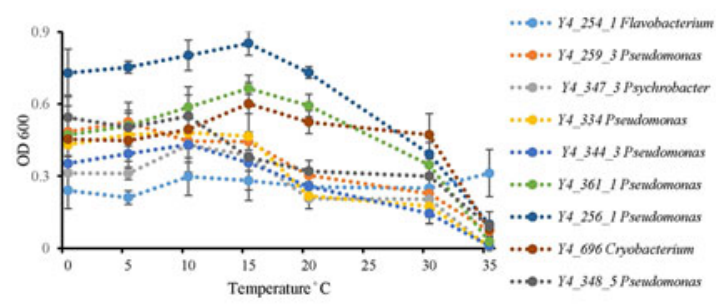

C

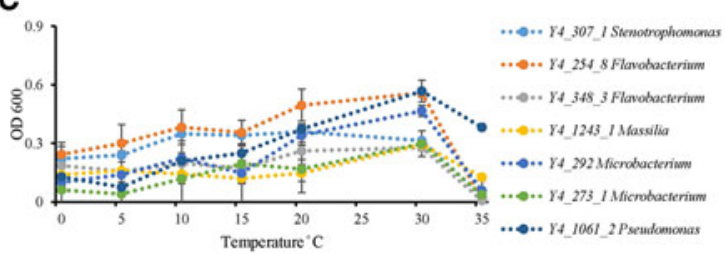

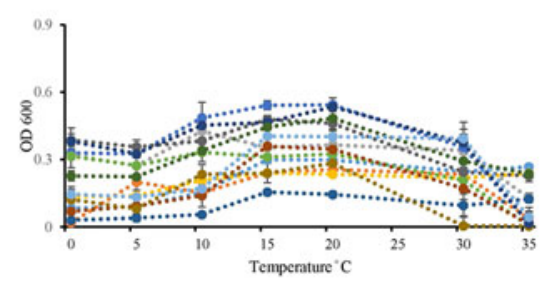
... Y4 as9 Flavebacterium -.. Y4_1s4_2Flavobacterium

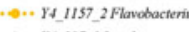
... Y4_287_llysobacier -... Y4.296_/Lssobacter

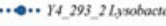
*... Y4 255_l Psychirobacter ..... Y4 2935 Bnevitacillus

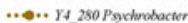

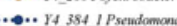
.... $\gamma_{4} 1246-2$ Sphingohar -

D

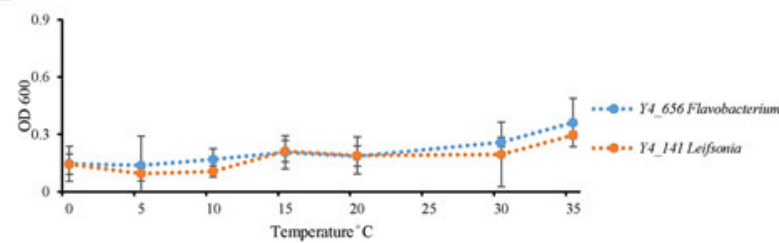

Fig. 2. Temperature effect on growth of ice core isolates. (A) Optimum growth temperatures were $15{ }^{\circ} \mathrm{C}$ or under $15{ }^{\circ} \mathrm{C}$ (strain $\mathrm{Y} 4 \_254 \_1$ in genus Flavobacterium; strains Y4_259_3, Y4_259_3, Y4_334, Y4_344_3, Y4_361_1, Y4_256_1, and Y4_348_5 in genus Pseudomonas; strain Y4_347_3 in genus Psychrobacter; and strain Y4_696 in genus Cryobacterium). (B) Optimum growth temperatures were 15 and $20{ }^{\circ} \mathrm{C}$ (strain Y4_581 in genus Rhodococcus; strains Y4_689, Y4_144_2, and Y4_1157_2 in genus Flavobacterium; strains Y4_287_1, Y4_296_1, and Y4_293_2 in genus Lysobacter; strains Y4_255_1 and Y4_280 in genus Psychrobacter; strain Y4_293_5 in genus Brevibacillus; strain Y4_384_1 in genus Pseudomonas; strain Y4_1246_2 in genus Sphingobacterium; strain Y4_284_4 in genus Stenotrophomonas). (C) Optimum growth temperatures was $30^{\circ} \mathrm{C}$ (strain Y4_307_1 in genus Stenotrophomonas; strains Y4_254_8 and Y4_348_3 in genus Flavobacterium; strain Y4_1243_1 in genus Massilia; strains Y4_292 and Y4_273_1 in genus Microbacterium; strain Y4_1061_2 in genus Pseudomonas). (D) Optimum growth temperatures were higher than $30^{\circ} \mathrm{C}$ (strain Y4_656 in genus Flavobacterium; strain Y4_141 in genus Leifsonia). Different colors refer to different strains. 


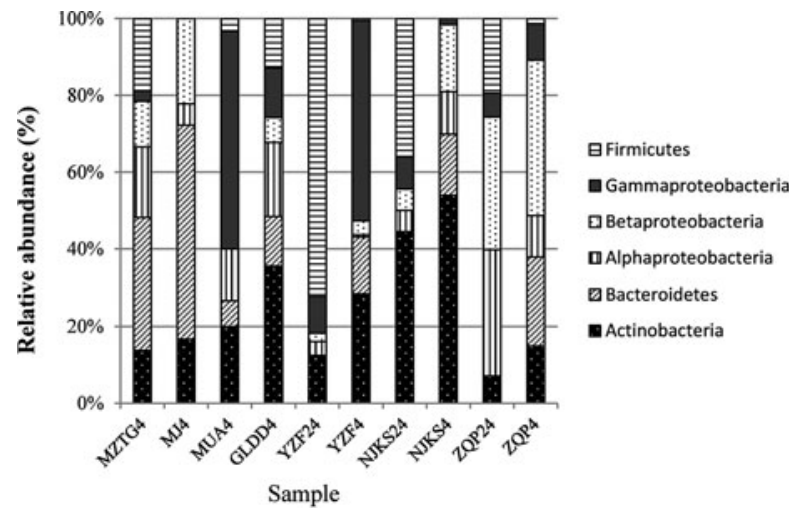

Fig. 3. Relative abundance of isolates recovered from culturing at 4 and $24{ }^{\circ} \mathrm{C}$, and of sequences in $16 \mathrm{~S}$ rRNA clone libraries. MZTG4, MJ4, MUA4, GLDD4, YZF4, NJKS4, and ZQP4 were incubated aerobically at $4{ }^{\circ} \mathrm{C}$. YZF24, NJKS24, and ZQP24 were incubated aerobically at $24^{\circ} \mathrm{C}$. NJKSC, YZFC, and ZQPC were $16 \mathrm{~S}$ rRNA clone libraries.

After quality checking and removal of chimeric sequences, a total of $34716 \mathrm{~S}$ rRNA sequences were obtained from the clone library, 98 in YZF, 142 in NJKS, and 107 in ZQP. Coverage of YZF, NJKS, and ZQP libraries were 82, 65 , and $73 \%$, respectively. The genera Cryobacterium (30\%) and Flavobacterium (23\%) were dominant in YZF, while Polaromonas, Cryobacterium, and Flavobacterium dominated in NJKS (40\% of total sequences). Clones related to two unclassified genera in Microbacteriaceae represented $43 \%$ of all clones recovered from ZQP.

The collection of isolates recovered from 4 and $24{ }^{\circ} \mathrm{C}$ incubations of YZF, NJKS, and ZQP had differing composition (Fig. 3). At the genus level, isolate compositions from all seven ice cores were grouped based on different incubation temperatures (Fig. 4, Bray-Curtis similarity). Isolate compositions of $\mathrm{YZF}, \mathrm{NJKS}$, and ZQP from $24{ }^{\circ} \mathrm{C}$ incubation were separated from similar ice core samples incubated at $4{ }^{\circ} \mathrm{C}$,
Table 5. Assemblages dissimilarity test based on one-way ANOSIM using Bray-Curtis distance. Values in boldface indicate significant differences $(P<0.05$, sequential Bonferroni-corrected) among isolate compositions recovered from 4 and $24{ }^{\circ} \mathrm{C}$ incubations and bacterial composition from clone libraries

\begin{tabular}{lccc}
\hline & $R$ & $P$ & Permutations \\
\hline $4{ }^{\circ} \mathrm{C}$ incubations and $24{ }^{\circ} \mathrm{C}$ & 0.391 & $\mathbf{0 . 0 0 1 4}$ & 9999 \\
incubations & & & \\
$4{ }^{\circ} \mathrm{C}$ incubations and clone libraries & 0.250 & 0.1131 & 9999 \\
Clone libraries and $24{ }^{\circ} \mathrm{C}$ incubations & 0.999 & $\mathbf{0 . 0 0 9 7}$ & 9999 \\
Global & 0.458 & $\mathbf{0 . 0 0 0 3}$ & 9999 \\
\hline
\end{tabular}

isolates from six ice cores from the current study and incubated at $4{ }^{\circ} \mathrm{C}$ grouped with isolates recovered at $4{ }^{\circ} \mathrm{C}$ from Tibetan Puruogangri (Zhang and others, 2008b) and Muzitage Ata (Xiang and others, 2005b) ice cores. Isolates recovered from $4{ }^{\circ} \mathrm{C}$ incubation also grouped together with bacterial composition from clone libraries of $\mathrm{YZF}$ and NJKS. Isolate compositions recovered from $4{ }^{\circ} \mathrm{C}$ incubation were similar to bacterial composition from clone libraries, but significantly different (ANOSIM, $P<0.001$ ) from isolate compositions recovered $24{ }^{\circ} \mathrm{C}$ incubation (Table 5). The difference between isolate compositions recovered from $24{ }^{\circ} \mathrm{C}$ incubation and bacterial composition from clone libraries was significant (ANOSIM, $P<0.001$; Table 4).

\section{DISCUSSION}

More than 800 isolates belonging to 53 genera were cultured from seven different ice cores collected from the TP. The isolates typify diverse culturable bacteria from different sources in high-altitude glaciers. The 13 major genera, which accounted for $78 \%$ of strains, occurred in ice cores located across geographic zones, from dry alpine desert (MZTG) to forest (ZQP). All of these genera were previously found in

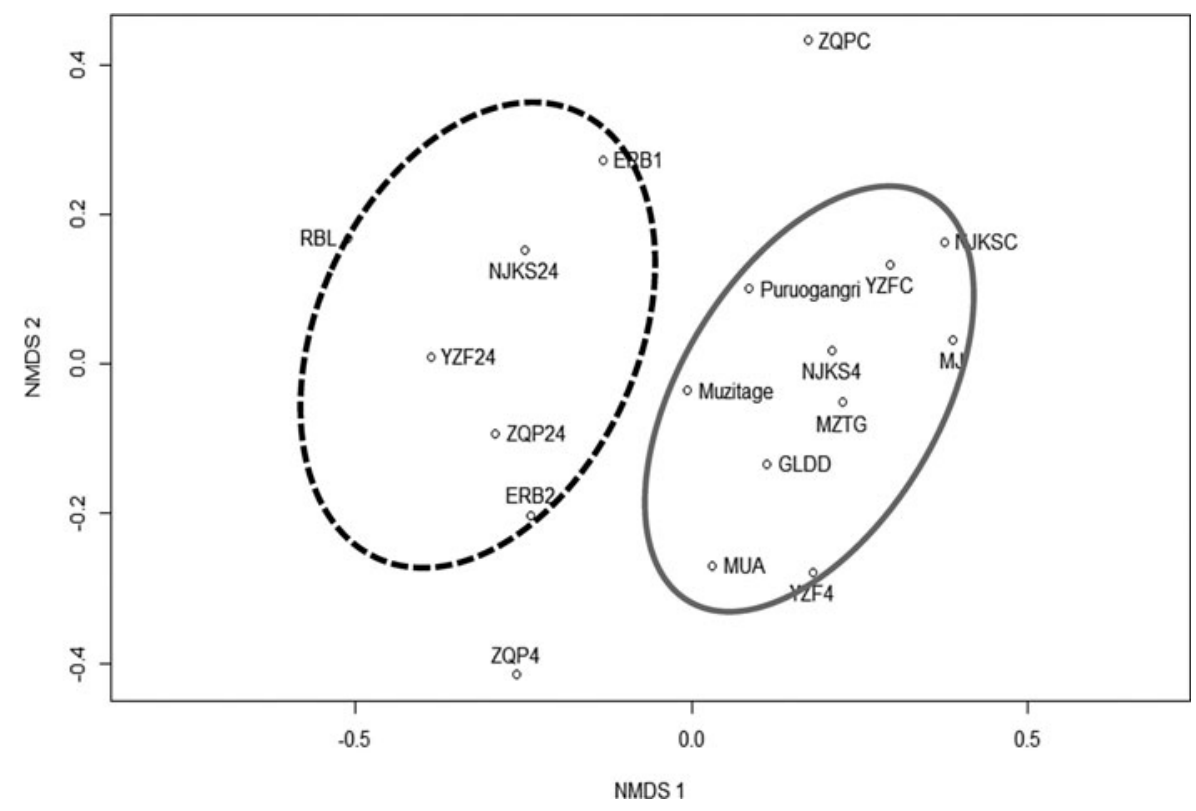

Fig. 4. nMDS analysis of the 887 isolates obtained in this study, 244 isolates from other TP ice cores (RBL, ERB1, ERB2, Puruogangri, Muzitage) (Zhang and others, 2007, 2008a, b; An and others, 2010; Shen and others, 2012), and YZF, NJKS, and ZQP clone libraries (YZFC, NJKSC, and ZQPC). The red circles indicate isolates incubated at $24{ }^{\circ} \mathrm{C}$, and the black circles indicate isolates and clone libraries derived from $4{ }^{\circ} \mathrm{C}$ incubations, except for ZQP, which did not group with the other isolates and clone libraries. 
glacier ice in the TP, the Arctic, and the Antarctic (Christner and others, 2000; Miteva and others, 2004; Zhang and others, 2008a, b). Half of abundant and common genera included strains most closely related to those from cold environments (Table 4). The relationship between our isolates and those from other ice core studies (Christner and others, 2003; Zhang and others, 2008b, 2010; Miteva and others, 2009) corroborates the findings of Christner and others (2000) that these cryosphere-related bacteria are widely distributed and may possess physiological mechanisms that confer resistance to atmospheric transport (i.e. high-UV irradiance) and freezing.

The abundant genera Bacillus, Flavobacterium, and Pseudomonas showed the widest distribution and highest abundance in Tibetan ice cores. These three genera are also the most commonly cultivated genera in cloud water which indicates that these genera remain viable during transport in the atmosphere, where they are subjected to strong selection pressures (Amato and others, 2005; Amato and others, 2007). The genus Bacillus widely exists in soil and water, and their endospore-forming ability has been reported as a strategy to endure freezing in glacial ice (Christner and others, 2000). Most of the strains (62\%) in the common genera (mainly those from the Actinobacteria and the Alphaproteobacteria and Gammaproteobacteria), were related to soil, aquatic, plant, and other environments (Table 4) indicating widespread and heterogeneous sources that may encompass selection pressures that differ from the abundant group.

The genera Cryobacterium, Paenisporosarcina, and Burkholderia were present in certain Tibetan ice cores (NJKS and YZF, GLDD and MZTG, ZQP, respectively) but were not widespread, which suggests a signature from the local environment around each glacier. The mainly plantassociated genus Burkholderia (Estrada-De Los Santos and others, 2001), for example, was only present in the ZQP ice core, which is surrounded by alpine forest.

The number of genera represented by more than five isolates sharply decreased with depth (Table 3). Three abundant genera (Bacillus, Flavobacterium, and Pseudomonas) showed relatively deep distribution, to depths of $80 \mathrm{~m}$. Sporosarcina, the dominant genus found in the deep ice samples $(>100 \mathrm{~m})$ has been reported in various icy environments (glacier, snow, and frozen soil from alpine, Arctic, and Antarctic) (Zhang and others, 2008a, b; Shivaji and others, 2013; Zdanowski and others, 2013; Yadav and others, 2015). Previous studies found that numbers of recoverable bacteria did not correlate directly with the age of the ice from 5 to 20000 years old (Christner and others, 2005). In 22 and $84 \mathrm{~m}$ long ice cores, bacterial isolates were layered, with different groups dominating along a depth gradient (Xiang and others, 2005b; Zhang and others, 2008a, b). Our study is the first to clearly show differences in dominant genera of culturable bacteria from the shallow and deep parts of ice cores. These differences should reflect either the influence of in situ processes on bacterial communities postdeposition, initial inputs of different bacterial communities at different times, or a combination of both. While bacteria may metabolize in situ in some ice environments, the rates of metabolism are extremely low (e.g. Tung and others, 2006), making it unlikely that a clearly detectable turnover between phylotypes would occur during the period of encasement in our study. We cannot, however, rule out the loss of phylotypes less tolerant of encasement.
Growth in a wide temperature range is likely a general survival strategy for bacteria encased in glacier ice. Ice core bacteria are transported from local or distant sources, depending on prevailing atmospheric circulation patterns. During transport, bacteria must endure temperature changes between the source environment and the glacier, either through broad tolerances of vegetative cells, spore formation, or other physiological modifications. All isolates tested in this study grew in a wide range of temperatures from 0 to $35^{\circ} \mathrm{C}$, had optimal growth temperatures of 10,15 , and $20^{\circ} \mathrm{C}$, and each isolate grew both at low temperature $\left(0\right.$ and $\left.4{ }^{\circ} \mathrm{C}\right)$ and high temperature $\left(30\right.$ and $\left.35^{\circ} \mathrm{C}\right)$. Snow bacteria isolated from the surface of glaciers have been found to have a wider growth temperature range, when compared with cultured representatives of the same species (Shen and others, 2014). In addition to our isolates from YZF ice core, bacteria from Guliya, Muztag Ata, Greenland, and Antarctic ice cores also grew in a wide temperature range (Christner, 2002; Miteva and others, 2004; Xiang and others, 2005b). These previous data, in combination with our data, show that wide growth temperature range is common among glacier-associated bacteria. While the previous studies focused on bacteria isolated from the surface of glaciers, our data show wide temperature adaptation in bacteria from all depths of the ice cores. Hence, we conclude that adaptation to broad temperature ranges is an important strategy for surviving the transition from source habitat to glacier ice.

Incubation temperature had an impact on the isolate assemblage recovered from a given ice core. Incubation temperature was a stronger driver of isolate assemblage than geographic location (Fig. 4), similar to results from glaciers in Western China (An and others, 2010). Incubation at 4 and $24{ }^{\circ} \mathrm{C}$ recovered different isolates from the same ice core (Fig. 3). The endospore-forming genus Bacillus dominated the $24{ }^{\circ} \mathrm{C}$ incubation while the psychrotolerant genus Cryobacterium dominated the $4{ }^{\circ} \mathrm{C}$ incubations from NJKS and YZF (Table 2). Previous studies suggested that incubation in low temperature obtain relatively more diverse bacteria in ice (Christner, 2002), implying that bacteria in ice are better adapted to low temperature. Bacterial assemblage determined via culture-independent molecular methods were statistically more similar to the culturable bacteria from the $4{ }^{\circ} \mathrm{C}$ incubations than the culturable bacteria obtained from the $24^{\circ} \mathrm{C}$ incubations (Table 5). Dominant genera found in clone libraries were also recovered in $4{ }^{\circ} \mathrm{C}$ incubations, such as Cryobacterium and Flavobacterium. However, the genus Burkholderia which was abundant in culturable organisms, but not detected in the clone library from ZQP, indicating the potential biases of culture-dependent methods and molecular methods. In particular, the relatively low coverage of three clone libraries $(82,65$, and $73 \%)$ may have limited the recovery of some potentially important clones. In spite of this, our results show that glacial ice contains diverse bacteria that can be revived after decades or centuries immured in ice. Further, the ice-associated bacteria identified in this study are capable of surviving at a wide range of temperatures, which suggests that temperature tolerance provides an important adaptive advantage to bacteria during atmospheric transport and deposition on ice. These new insights into the survival of cryosphere-associated bacteria highlight the importance of icy environments as refugia for microorganisms during periods of glaciation. 


\section{SUPPLEMENTARY MATERIAL}

The supplementary material for this article can be found at https://doi.org/10.1017/jog.2018.86

\section{ACKNOWLEDGEMENTS}

This study was financially supported by the International Partnership Program of Chinese Academy of Sciences (Grant No. 131C11KYSB20160061), the National Natural Science Foundation of China (Grant No. 41425004 and 41701085), and the National Basic Research Program of China (Grant No. 2015FY110100). The authors thank two reviewers and the editor Dr Tranter for their constructive comments.

\section{REFERENCES}

Altschul SF and 6 others (1997) Gapped BLAST and PSI-BLAST: a new generation of protein database search programs. Nucleic Acids Res., 25(17), 3389-3402 (doi: 10.1093/nar/25.17.3389)

Amato $P$ and 5 others (2005) Microbial population in cloud water at the Puy de Dome: implications for the chemistry of clouds. Atmos. Environ., 39(22), 4143-4153 (doi: 10.1016/j.atmosenv. 2005.04.002)

Amato P and 5 others (2007) Microorganisms isolated from the water phase of tropospheric clouds at the Puy de dome: major groups and growth abilities at low temperatures. FEMS Microbiol. Ecol., 59(2), 242-254 (http://dx.doi.org/10.1111/j.1574-6941. 2006.00199.x242-254)

An LZ, Chen Y, Xiang SR, Shang TC and Tian LD (2010) Differences in community composition of bacteria in four glaciers in western China. Biogeosciences, 7(6), 1937-1952 (doi: 10.5194/bg-71937-2010)

Bowman JP, McCammon SA, Brown MV, Nichols DS and McMeekin TA (1997) Diversity and association of psychrophilic bacteria in Antarctic sea ice. Appl. Environ. Microbiol., 63(8), 3068-3078

Christner BC (2002) Detection, recovery, isolation and characterization of bacteria in glacial ice and lake Vostok accretion ice. (Doctor thesis, The Ohio State University)

Christner BC and 5 others (2000) Recovery and identification of viable bacteria immured in glacial ice. Icarus, 144(2), 479-485 (doi: 10.1006/icar.1999.6288)

Christner BC, Mosley-Thompson E, Thompson LG and Reeve JN (2003) Bacterial recovery from ancient glacial ice. Environ. Microbiol., 5(5), 433-436 (doi: 10.1046/j.1462-2920.2003. 00422.x)

Christner BC, Mikucki JA, Foreman CM, Denson J and Priscu JC (2005) Glacial ice cores: a model system for developing extraterrestrial decontamination protocols. Icarus, 174(2), 572-584 (doi. org/10.1016/j.icarus.2004.10.027)

Estrada-De Los Santos P, Bustillos-Cristales $\mathrm{R}$ and CaballeroMellado J (2001) Burkholderia, a genus rich in plant-associated nitrogen fixers with wide environmental and geographic distribution. Appl. Environ. Microbiol., 67(6), 2790-2798 (doi: 10.1128/ AEM.67.6.2790-2798.2001)

Hammer $\varnothing$, Harper D and Ryan P (2001) PAST-PAlaeontological STatistics, ver. 1.89. Palaeontol. Electron., 4(1), 1-9

Kan JJ, Crump BC, Wang K and Chen F (2006) Bacterioplankton community in Chesapeake Bay: predictable or random assemblages. Limnol. Oceanogr., 51(5), 2157-2169

Kemp PF and Aller JY (2004) Bacterial diversity in aquatic and other environments: what $16 \mathrm{~S}$ rDNA libraries can tell us. FEMS Microbiol. Ecol., 47(2), 161-177 (http://dx.doi.org/10.1016/ S0168-6496 (03)00257-5)

Kim OS and 11 others (2012) Introducing EzTaxon-e: a prokaryotic $16 \mathrm{~S}$ rRNA gene sequence database with phylotypes that represent uncultured species. Int. J. Syst. Evol. Micrbiol., 62(Pt 3), 716-721

Lane DJ (1991) 16S/23S rRNA sequencing. In Stackebrandt E and Goodfellow M, eds. Nucleic acid techniques in bacterial systematics. John Wiley@Sons, New York, 125-175

Margesin R and Miteva V (2011) Diversity and ecology of psychrophilic microorganisms. Res. Microbiol., 162(3), 346-361 (doi: 10.1016/j.resmic.2010.12.004)

Miteva VI, Sheridan PP and Brenchley JE (2004) Phylogenetic and physiological diversity of microorganisms isolated from a deep Greenland glacier ice core. Appl. Environ. Microbiol., 70(1), 202-213 (doi: 10.1128/AEM.70.1.202-213.2004)

Miteva V, Teacher C, Sowers T and Brenchley J (2009) Comparison of the microbial diversity at different depths of the GISP2 Greenland ice core in relationship to deposition climates. Environ. Microbiol., 11(3), 640-656 (doi: 10.1111/j.14622920.2008.01835.x)

Oksanen J and 7 others (2009) Vegan: community ecology package. $R$ package version $1.15-2$

Priscu JC, Christner BC, Foreman CM and Royston-Bishop G (2007) Biological material in Ice Cores. Encycl. Quat. Sci., 2, 11561166

Pruesse E and 6 others (2007) SILVA: a comprehensive online resource for quality checked and aligned ribosomal RNA sequence data compatible with ARB. Nucleic Acids Res., 35 (21), 7188-7196 (doi: 10.1093/nar/gkm864)

Qiu J (2008) The third pole. Nature, 454(7203), 393-396

Reasoner DJ and Geldreich EE (1985) A new medium for the enumeration and subculture of bacteria from potable water. Appl. Environ. Microbiol., 49(1), 1-7 (doi: 0099-2240/85/010001-07 $\$ 02.00 / 0)$

Santibanez PA, McConell JR and Priscu JC (2016) A flow cytometric method to measure prokaryotic records in ice cores: an example from the West Antarctic Ice Sheet Divide drilling site. J. Glaciol., 62(234), 655-673 (doi:http://dx.doi.org/10.1017/jog.2016.50)

Segawa T, Ushida K, Narita H, Kanda H and Kohshima S (2010) Bacterial communities in two Antarctic ice cores analyzed by 16S rRNA gene sequencing analysis. Polar Sci., 4(2), 215-227 (doi: 10.1016/j.polar.2010.05.003)

Shen L and 7 others (2012) Variation of culturable bacteria along depth in the East Rongbuk ice core, Mt. Everest. Geosci. Front., 3(3), 327-334 (doi: 10.1016/j.gsf.2011.12.013)

Shen L and 6 others (2014) Downward-shifting temperature range for the growth of snow-bacteria on glaciers of the Tibetan Plateau. Geomicrobiol. J., 31, 779-781 (doi:org/10.1080/01490451. 2014. 891418)

Shen L and 5 others (2018) Variation with depth of the abundance, diversity and pigmentation of culturable bacteria in a deep ice core from the Yuzhufeng Glacier, Tibetan Plateau. Extremophiles, 22(1), 29-38

Shivaji S and 9 others (2013) Antarctic ice core samples: culturable bacterial diversity. Res. Microbiol., 164(1), 70-82 (doi.org/10. 1016/j.resmic.2012.09.001)

Stackebrandt E and Goebel BM (1994) A place for DNA-DNA reassociation and $16 \mathrm{~s}$ ribosomal-RNA sequence-analysis in the present species definition in bacteriology. Int. J. Syst. Evol. Micrbiol., 44(4), 846-849

Tung HC, Price PB, Bramall NE and Vrdoljak G (2006) Microorganisms metabolizing on clay grains in 3-km-deep Greenland basal ice. Astrobiology, 6(1), 69-86

Warnes GR, Bolker B and Lumley T (2009) Gplots: various R programming tools for plotting data. $R$ Package Version, 2(4)

Wood SN (2006) Generalized additive models: an introduction with $R$. Chapman and Hall/CRC, Boca Raton, Florida, USA

Xiang SR and 8 others (2005a) Vertical quantitative and dominant population distribution of the bacteria isolated from the Muztagata ice core. Sci. China Ser. D, 48(10), 1728-1739 (doi: 10.1360/02YD0210)

Xiang SR, Yao TD, An LZ, Xu BL and Wang JX (2005b) 16S rRNA sequences and differences in bacteria isolated from the Muztag 
Ata glacier at increasing depths. Appl. Environ. Microbiol., 71(8), 4619-4627 (doi: 10.1128/AEM.71.8.4619-4627.2005)

Yadav AN and 5 others (2015) Culturable diversity and functional annotation of psychrotrophic bacteria from cold desert of Leh Ladakh (India). World J. Microbiol. Biotechnol., 31(1), 95-108 (doi: 10.1007/s11274-014-1768-z)

Yao TD and 6 others (2008) Bacteria variabilities in a Tibetan ice core and their relations with climate change. Global Biogeochem. Cycles, 22(4), GB4017 (doi: 10.1029/2007G B003140)

Zdanowski MK and 7 others (2013) Culturable bacteria community development in postglacial soils of Ecology Glacier, King George Island, Antarctica. Polar Biol., 36(4), 511-527 (doi: 10.1007/ s00300-012-1278-0)
Zhang S, Hou S, Ma X, Qin D and Chen T (2007) Culturable bacteria in Himalayan glacial ice in response to atmospheric circulation. Biogeosciences, 4(1), 1-9

Zhang S, Hou S, Wu Y and Qin D (2008a) Bacteria in Himalayan glacial ice and its relationship to dust. Biogeosciences, 5(6), 1741-1750 (doi: 10.5194/bg-5-1741-2008)

Zhang XF, Yao TD, Tian LD, Xu SJ and An LZ (2008b) Phylogenetic and physiological diversity of bacteria isolated from Puruogangri ice core. Microbial. Ecol., 55(3), 476-488 (doi: 10.1007/s00248007-9293-3)

Zhang SH, Hou SG, Yang GL and Wang JH (2010) Bacterial community in the East Rongbuk Glacier, Mt. Qomolangma (Everest) by culture and culture-independent methods. Microbiol. Res., 165 (4), 336-345 (doi: 10.1016/j.micres.2009.08.002)

MS received 23 February 2018 and accepted in revised form 17 October 2018; first published online 18 December 2018 